Check for updates

Cite this: RSC Adv., 2017, 7, 25627

\title{
Effect of an improved gas diffusion cathode on carbamazepine removal using the electro-Fenton process
}

\author{
Wei Wang, Yaobin Lu, Haiping Luo, Guangli Liu (DD * and Renduo Zhang
}

The aim of this study was to investigate the effect of the diffusion layer of a gas diffusion cathode (GDC) on $\mathrm{H}_{2} \mathrm{O}_{2}$ production to enhance carbamazepine removal using the electro-Fenton process. The diffusion layer was made by carbon black and polytetrafluoroethylene with sodium sulfate $\left(\mathrm{Na}_{2} \mathrm{SO}_{4}\right)$ as a pore former. Different ratios of $\mathrm{Na}_{2} \mathrm{SO}_{4}$ to carbon black (w/w) (i.e., $0 \%, 50 \%, 100 \%, 150 \%$, and 200\%) in the diffusion layer were tested. With an increase of the ratio, the average pore size in the diffusion layer and the electro-activity in the GDC increased simultaneously, which resulted in a higher mass transfer coefficient of oxygen and $\mathrm{H}_{2} \mathrm{O}_{2}$ production. In an undivided cell with platinum as the anode and $5.0 \mathrm{~g} \mathrm{~L}^{-1} \mathrm{Na}_{2} \mathrm{SO}_{4}$ as the electrolyte, a maximum $\mathrm{H}_{2} \mathrm{O}_{2}$ concentration of $630 \mathrm{mg} \mathrm{L}^{-1}$ was achieved within $120 \mathrm{~min}$ in the GDC with the ratio of $150 \%$. With an initial carbamazepine concentration of $50 \mathrm{mg} \mathrm{L}^{-1}$ and a current density of $5.0 \mathrm{~mA} \mathrm{~cm}{ }^{-2}$, the maximum carbamazepine removal efficiency and rate reached $71 \%$ and $35.5 \mathrm{mg} \mathrm{L}^{-1} \mathrm{~h}^{-1}$, respectively. The removal rates in this study were much higher than those in the literature (35.5 vs. $0.03-10.0 \mathrm{mg} \mathrm{L}^{-1} \mathrm{~h}^{-1}$ ), mainly attributable to the diffusion layer modified by the pore former, which accelerated oxygen transfer and boosted $\mathrm{H}_{2} \mathrm{O}_{2}$ production. The results from this study should be useful to remove carbamazepine from wastewater treatment using the electro-Fenton (EF) process with improvement of pore structure in the diffusion layer of GDC.

Received 2nd April 2017

Accepted 5th May 2017

DOI: $10.1039 / \mathrm{c} 7 \mathrm{ra03793g}$

rsc.li/rsc-advances according to the production reaction of hydrogen peroxide $\left(\mathrm{O}_{2}+\right.$ $\left.2 \mathrm{e}^{-}+2 \mathrm{H}^{+} \rightarrow \mathrm{H}_{2} \mathrm{O}_{2}\right) \cdot{ }^{4,8}$

Usage of the gas diffusion cathode (GDC) is a promising way to accelerate oxygen diffusion and $\mathrm{H}_{2} \mathrm{O}_{2}$ production. ${ }^{4,8}$ The GDC is usually composed of three layers, that is, a diffusion layer, a current collector layer, and a catalyst layer. ${ }^{9}$ Because of high specific surface area and porosity of the diffusion layer, oxygen gas can efficiently pass through the diffusion layer and reach the interface between the catalyst layer and electrolyte, resulting in low energy consumption and high production of $\mathrm{H}_{2} \mathrm{O}_{2}$. Therefore, the pore structure of the diffusion layer plays an important role in oxygen transfer, which has been studied for the fuel cells. ${ }^{4,9}$ Because of low costs, carbon black and polytetrafluoroethylene (PTFE) have been commonly used as the raw materials to make the diffusion layer. ${ }^{4}$ PTFE is used the binder of carbon black to form many pores as gas channels. ${ }^{8}$ Carbonand PTEF-based GDC has been applied to remove refractory organics from solutions in the EF process., ${ }^{5,10}$

As one of typical pharmaceuticals and personal care products, carbamazepine (CBZ) has been widely used. ${ }^{11}$ The total consumption of CBZ is about $1014 \mathrm{t}$ in the world each year, which accounted for $96 \%$ of the total pharmaceutical consumption in $2007 .{ }^{12}$ However, overdose and metabolites of CBZ may result in damage of human's liver and emopoietic systems. ${ }^{13} \mathrm{CBZ}$ has an amide structure that is stable and difficult to be degraded. The benzene ring of CBZ is a closed
Guangdong Provincial Key Laboratory of Environmental Pollution Control and Remediation Technology, School of Environmental Science and Engineering, Sun Yat-sen University, Guangzhou 510275, China.E-mail: liugl@mail.sysu.edu.cn 
conjugate system and form $\pi$ bond, resulting in high stability of CBZ. ${ }^{14}$ Moreover, the Henry coefficient of CBZ is as low as $1.09 \times$ $10^{-5} \mathrm{~Pa} \mathrm{~m}^{3} \mathrm{~mol}^{-1}$ so that $\mathrm{CBZ}$ cannot be efficiently removed by the physical methods, such as air stripping treatment. ${ }^{15,16}$ The EF process has been utilized to degrade CBZ. ${ }^{17,18}$ Komtchou et al. ${ }^{17}$ demonstrated that $66 \%$ of $12 \mathrm{mg} \mathrm{L}^{-1} \mathrm{CBZ}$ was removed within $120 \mathrm{~min}$ in the EF process under a current density of $1.8 \mathrm{~mA}$ $\mathrm{cm}^{-2}(0.2 \mathrm{~A})$. A new material of carbon fiber coupled with cobalt phthalocyanine has been used as the cathode in the EF process, resulting in $97 \%$ of CBZ removal within $120 \mathrm{~min} .{ }^{17}$ However, CBZ removal rates in the EF process are still low. For example, a CBZ removal rate of $4.0 \mathrm{mg} \mathrm{L}^{-1} \mathrm{~h}^{-1}$ with the EF process has been reported, ${ }^{17}$ which is only $40 \%$ of that in the Fenton-like process. ${ }^{19}$ To enhance the EF process, several strategies have been developed, including new catalysts, new configuration, etc. ${ }^{\mathbf{6 , 2 0 , 2 1}}$ Nevertheless, the idea using the diffusion layer morphology to enhance the EF process on the recalcitrant organic pollutant removal has not been examined as far as we know.

The objective of this study was to investigate the effect of improved pore structure in the diffusion layer on $\mathrm{H}_{2} \mathrm{O}_{2}$ production to enhance $\mathrm{CBZ}$ degradation using the EF process. Different morphology and porosities of the diffusion layer with sodium sulfate $\left(\mathrm{Na}_{2} \mathrm{SO}_{4}\right)$ as the pore former were characterized. Production of $\mathrm{H}_{2} \mathrm{O}_{2}$ and $\mathrm{CBZ}$ degradation in the EF process were determined. The mechanism of the effect of diffusion layer on the CBZ degradation was discussed.

\section{Experiment}

\subsection{GDC preparation}

The diffusion layer was prepared with $\mathrm{Na}_{2} \mathrm{SO}_{4}$ as the pore former as follows. ${ }^{\mathbf{8}, 22}$ Carbon black (EC-300J, Ketjenblack, Japan) of $1200 \mathrm{mg}$ was mixed with each of different $\mathrm{Na}_{2} \mathrm{SO}_{4}$ dosages to obtain mass ratios of $\mathrm{Na}_{2} \mathrm{SO}_{4}$ to carbon black of $0 \%$, $50 \%, 100 \%, 150 \%$, and $200 \%$. Each mixture was added with 30 $\mathrm{mL}$ of ethyl alcohol and stirred with ultrasonic treatment for 30 min. A PTFE emulsion (60 wt $\%$, Hesen electric Co. Ltd., Shanghai, China) of $2800 \mathrm{mg}$ was then added slowly into the mixture with agitation and ultrasonic treatment for $30 \mathrm{~min}$. After excess alcohol evaporated at room temperature, the final mixture with dough-like was rolled on the stainless steel mesh (90 meshes, length $\times$ width $\times$ thickness $=8 \mathrm{~cm} \times 4 \mathrm{~cm} \times 0.2$ $\mathrm{mm}$ ) and formed $0.8 \mathrm{~mm}$ thickness of diffusion layer. The catalyst layer in the GDC was prepared as the same as the diffusion layer, except with a mass ratio $3: 1$ of carbon black to PTFE without $\mathrm{Na}_{2} \mathrm{SO}_{4}$ addition. The catalyst layer was formed by rolling on another side of the stainless steel mesh. The GDC was boiled in the deionized water for $10 \mathrm{~min}$ and repeated for three times to remove $\mathrm{Na}_{2} \mathrm{SO}_{4}$ in the diffusion layer. Finally, the GDC was dried at $105{ }^{\circ} \mathrm{C}$ for $12 \mathrm{~h}$. A GDC without $\mathrm{Na}_{2} \mathrm{SO}_{4}$ addition was sintered at $450{ }^{\circ} \mathrm{C}$ for $30 \mathrm{~min}$ and taken as the control. The total thickness of GDC was about $1 \mathrm{~mm}$.

\subsection{Reactor setup and operation}

Undivided reactor was constructed with a cube plexiglass $(4 \mathrm{~cm} \times 4 \mathrm{~cm} \times 4 \mathrm{~cm})$. A hole in diameter of $3 \mathrm{~cm}$ was made in the cube plexiglass with an effective volume of $28 \mathrm{~mL}$ (diameter $\times$ length $=3 \mathrm{~cm} \times 4 \mathrm{~cm})$. The GDC had an effective area of $7 \mathrm{~cm}^{2}$ with a diameter of $3.0 \mathrm{~cm}$. The distance between the anode and cathode was $4 \mathrm{~cm}$. The length and diameter of the $\mathrm{Pt}$ anode were $3.3 \mathrm{~cm}$ and $0.5 \mathrm{~mm}$, respectively. $\mathrm{A} \mathrm{Na}_{2} \mathrm{SO}_{4}$ solution of $5 \mathrm{~g} \mathrm{~L}^{-1}$ as the supporting electrolyte and a current density of $50.0 \mathrm{~A} \mathrm{~m}^{-2}$ were used throughout all the tests. A solution of $50 \mathrm{mg} \mathrm{L}^{-1} \mathrm{CBZ}$ was used in the undivided reactor for the experiments.

\subsection{Measurements and calculations}

The diffusion layer morphology was observed using a Field Emission Scanning Electron Microscope (FESEM, JSM-6330F, Electron Corp., Japan). Porosities of the diffusion layer on the stainless steel meshes were determined using an automatic specific surface area and porosity analyzer (ASAP, 2020 (M), Micromeritics Corp., USA). Pore structures and distributions in the diffusion layers were determined using the $\mathrm{N}_{2}$ sorptiondesorption method.

Oxygen transfer in the diffusion layer was measured in a sealed glass bottle with $100 \mathrm{~mL}$ of $5 \mathrm{~g} \mathrm{~L}^{-1} \mathrm{Na}_{2} \mathrm{SO}_{4}$ solution. The diffusion layer with an effective surface area of $7 \mathrm{~cm}^{2}$ was installed at one side of the glass bottle as the separator between the $\mathrm{Na}_{2} \mathrm{SO}_{4}$ solution inside and the air outside. Before the tests, the $\mathrm{Na}_{2} \mathrm{SO}_{4}$ solution was aerated by pure $\mathrm{N}_{2}$ at least $15 \mathrm{~min}$ to keep the dissolved oxygen concentration $<1 \mathrm{mg}$ $\mathrm{L}^{-1}$. Then dissolved oxygen concentrations in the $\mathrm{Na}_{2} \mathrm{SO}_{4}$ solution were recorded with a dissolved oxygen meter (YSI 550A, Xylem Inc., USA). The mass transfer coefficient of oxygen was calculated as follows: ${ }^{23,24}$

$$
k_{0}=-\frac{V}{A t} \ln \left(\frac{C_{1}-C_{2}}{C_{1}}\right)
$$

where $V$ is the liquid volume in the sealed gas bottle $(100 \mathrm{~mL}), A$ is the projected surface area of the diffusion layer $\left(7 \mathrm{~cm}^{2}\right)$, and $C_{1}$ and $C_{2}$ are the saturated oxygen concentration $\left(\mathrm{mg} \mathrm{L}^{-1}\right)$ and dissolved oxygen concentration $\left(\mathrm{mg} \mathrm{L}^{-1}\right)$ in the sealed gas bottle at time $t$, respectively. The linear sweep voltammetry (LSV) measurement was carried out using an electrochemical station (CHI 660C, Shanghai Chenhua Inc., China). The calomel electrode, Pt anode, and the GDC were used as the reference electrode, the counter electrode, and the working electrode, respectively. The scan range was from 0.0 to $-2500 \mathrm{mV}$ with a scan rate of $10 \mathrm{mV} \mathrm{s}^{-1}$. Before the LSV measurements were carried out, the reactors including the GDCs were fulfilled with the electrolyte at least for $24 \mathrm{~h}$ to reach a stable balance among electrolyte, oxygen, and the GDCs.

The $\mathrm{H}_{2} \mathrm{O}_{2}$ concentration was determined by the colorimetric standard method. ${ }^{25}$ The CBZ concentration was determined with a high pressure liquid chromatograph (HPLC, P230II, Dalian Yilite analytic Instrument Co. Ltd., China). The mobile phase was the acetonitrile solution $(50 \%, \mathrm{v} / \mathrm{v})$. The CBZ removal efficiency was estimated by

$$
E=100 \% \frac{C_{0}-C_{1}}{C_{0}}
$$


where $E$ is the CBZ removal efficiency (\%), and $C_{0}$ and $C_{1}$ are the initial and final $\mathrm{CBZ}$ concentrations $\left(\mathrm{mg} \mathrm{L}^{-1}\right)$, respectively. The CBZ removal rate was calculated by

$$
R=\frac{C_{0}-C_{1}}{t}
$$

where $R$ is the CBZ removal rate $\left(\mathrm{mg} \mathrm{L}^{-1} \mathrm{~h}^{-1}\right)$ and $t$ is the reaction time (h).

\section{Results and discussions}

\subsection{Characterization of gas diffusion layer in the cathode}

The SEM images on the surface morphology of diffusion layers using different $\mathrm{Na}_{2} \mathrm{SO}_{4}$ dosages as pore former are shown in Fig. 1. With increase of the ratios of $\mathrm{Na}_{2} \mathrm{SO}_{4}$ to carbon black from $0 \%$ to $200 \%$, the surface morphology in the diffusion layers became coarser and more porous. As shown in Fig. 2, the ranges of pore sizes from 4 to $80 \mathrm{~nm}$ were similar among the different diffusion layers. However, the proportions of larger pores $(>20 \mathrm{~nm})$ were greater in the diffusion layers with higher amount of $\mathrm{Na}_{2} \mathrm{SO}_{4}$. The characteristics of the diffusion layers with the different ratios of $\mathrm{Na}_{2} \mathrm{SO}_{4}$ to carbon black are listed in Table 1. Average pore sizes in the diffusion layers with the different ratios of $\mathrm{Na}_{2} \mathrm{SO}_{4}$ to carbon black were in the order of $19.3 \mathrm{~nm}(200 \%)>18.7 \mathrm{~nm}(150 \%)>18.1 \mathrm{~nm}(100 \%)>17.5 \mathrm{~nm}$ $(50 \%)>17.1 \mathrm{~nm}(\mathrm{CK})>16.6 \mathrm{~nm}(0 \%)$. Total porosities in the different diffusion layers changed from $10.1 \%$ to $29.1 \%$ with
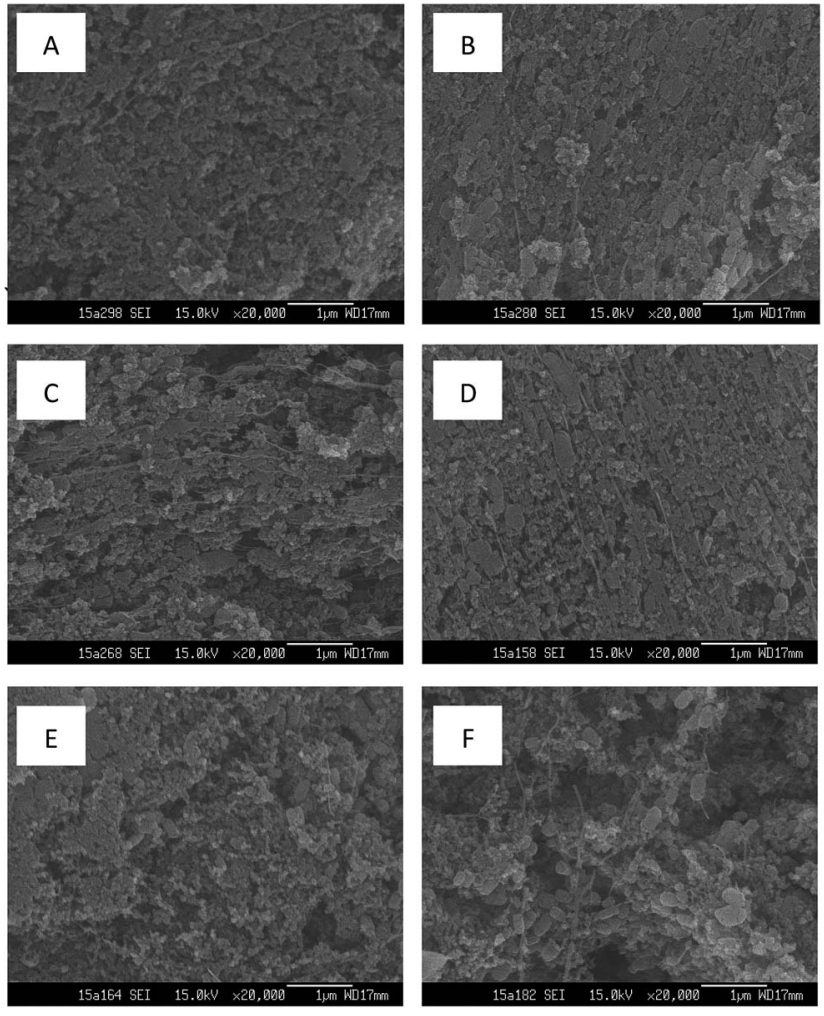

Fig. 1 SEM images on morphology of the diffusion layer for (A) the control check, and with ratios of $\mathrm{Na}_{2} \mathrm{SO}_{4}$ to carbon black of (B) $0 \%$, (C) $50 \%$, (D) $100 \%$, (E) $150 \%$, and (F) $200 \%$.
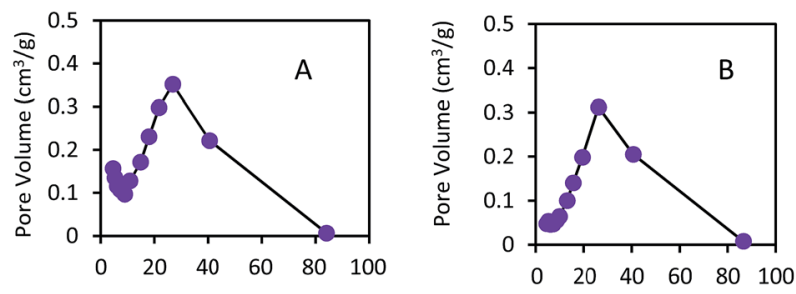

Pore diameter $(\mathrm{nm})$

Pore diameter $(\mathrm{nm})$
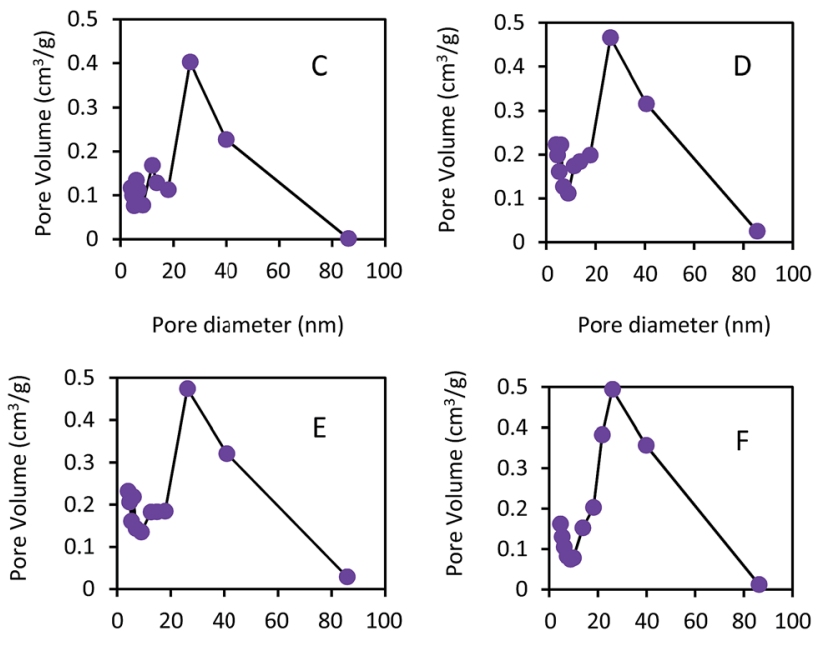

Pore diameter $(\mathrm{nm})$

Pore diameter $(\mathrm{nm})$

Fig. 2 The pore size distributions of the diffusion layer with different content of pore former for (A) the control, and with ratios of $\mathrm{Na}_{2} \mathrm{SO}_{4}$ to carbon black of (B) $0 \%$, (C) $50 \%$, (D) $100 \%$, (E) $150 \%$, and (F) $200 \%$.

increase of the ratios. The result of increase of pore sizes and porosities in the diffusion layers with the $\mathrm{Na}_{2} \mathrm{SO}_{4}$ amount was consistent with those reported in the polymer electrolyte fuel cells (PEFCs). ${ }^{26,27}$ Pores in the diffusion layers of the fuel cell could be increased by adding $20 \%$ (wt\%) ammonium slat as pore former. ${ }^{26}$ With increase of sucrose dosages from 25 to 75 (w/o) as pore former in the diffusion layer of the fuel cell, the porosity of diffusion layer increased from $36 \%$ to $50 \%{ }^{27}$

The $k_{0}$ values increased with the ratios of $\mathrm{Na}_{2} \mathrm{SO}_{4}$ to carbon black, that is, $19.1 \times 10^{-4} \mathrm{~cm} \mathrm{~s}^{-1}(200 \%)>18.0 \times 10^{-4} \mathrm{~cm} \mathrm{~s}^{-1}$ $(150 \%)>17.2 \times 10^{-4} \mathrm{~cm} \mathrm{~s}^{-1}(100 \%)>17.0 \times 10^{-4} \mathrm{~cm} \mathrm{~s}^{-1}(50 \%)$ $>15.8 \times 10^{-4} \mathrm{~cm} \mathrm{~s}^{-1}(\mathrm{CK})>15.2 \times 10^{-4} \mathrm{~cm} \mathrm{~s}^{-1}(0 \%)$. The $k_{0}$ values were linearly correlated to the porosities (with a correlation coefficient $R=0.973$ ), indicating that the mass transfer capacity of oxygen was attributable to the porosity in the diffusion layers. However, a severely water leakage in the diffusion layer occurred when the ratio of $\mathrm{Na}_{2} \mathrm{SO}_{4}$ to carbon black increased to $300 \%$ (data not shown). To keep a stable $\mathrm{H}_{2} \mathrm{O}_{2}$ production, the maximum ratio of $\mathrm{Na}_{2} \mathrm{SO}_{4}$ to carbon black was kept at $200 \%(\mathrm{w} / \mathrm{w})$ in the following tests. The $k_{0}$ values in the diffusion layer was much higher than those in cation exchange membrane $\left(0.94 \times 10^{-4} \mathrm{~cm} \mathrm{~s}^{-1}\right)$ and ultrafiltration membrane $\left(0.19 \times 10^{-4} \mathrm{~cm} \mathrm{~s}^{-1}\right),{ }^{23}$ suggesting that the diffusion layer made by carbon black had higher oxygen transfer capacity than those by other materials. The $k_{0}$ values in this study were 
Table 1 Characteristics of the diffusion layers with different ratios of $\mathrm{Na}_{2} \mathrm{SO}_{4}$ to carbon black

\begin{tabular}{lll}
\hline $\begin{array}{l}\text { Ratio of } \mathrm{Na}_{2} \mathrm{SO}_{4} \text { to } \\
\text { carbon black }\end{array}$ & $\begin{array}{l}\text { Total porosity } \\
(\%)\end{array}$ & $\begin{array}{l}\text { Average pore } \\
\text { size (nm) }\end{array}$ \\
\hline $0 \%$ & 10.1 & 16.6 \\
$50 \%$ & 20.2 & 17.5 \\
$100 \%$ & 24.1 & 18.1 \\
$150 \%$ & 27.3 & 18.7 \\
$200 \%$ & 29.1 & 19.3 \\
Control check & 15.3 & 17.1 \\
\hline
\end{tabular}

comparable to the mass transfer coefficient $\left(27.0 \times 10^{-4} \mathrm{~cm}\right.$ $\mathrm{s}^{-1}$ ) in the electrochemical generation of $\mathrm{H}_{2} \mathrm{O}_{2} \cdot{ }^{3}$ Moreover, the heat treatment $\left(300-500{ }^{\circ} \mathrm{C}\right)$ of carbon black could increase carbon-oxygen surface groups on the carbon black particles and improve the lap shear strength of the adhesive joint between carbon black and adhesive. ${ }^{28}$

\subsection{Performance of gas diffusion cathode}

The linear sweep voltammetry measurements in different GDCs are shown in Fig. 3. With the different ratios of $\mathrm{Na}_{2} \mathrm{SO}_{4}$ to carbon black $(\mathrm{w} / \mathrm{w})$ in the diffusion layer, GDCs showed different oxidation and reduction activities with the same catalyst layers. At the potential of $-2.0 \mathrm{~V}$, the maximum current reached -0.171 A using the GDC with the ratio of $200 \%$. GDCs with the ratios of $150 \%$ and $100 \%$ had almost the same current of $-0.162 \mathrm{~A}$. The maximum current of $-0.117 \mathrm{~A}$ was obtained in the GDC with the ration of $0 \%$. The result demonstrated that $\mathrm{Na}_{2} \mathrm{SO}_{4}$ as pore former could enhance the activity of GDC, which was consistent with those with other pore-forming agents, such as $\left(\mathrm{NH}_{4}\right)_{2} \mathrm{C}_{2} \mathrm{O}_{4}, \mathrm{NH}_{4} \mathrm{HCO}_{3}, \mathrm{NaCl}$, and PEG-200, reported in the literature. ${ }^{29}$ Large average pore sizes and high mass transfer coefficients in the diffusion layers could result in high oxidation-reduction activity of GDCs according to the diffusion layer characteristics mentioned above.

As shown in Fig. 4A, the $\mathrm{H}_{2} \mathrm{O}_{2}$ concentrations increased with the operation time under the current density of $5.0 \mathrm{~mA} \mathrm{~cm}{ }^{-2}$.

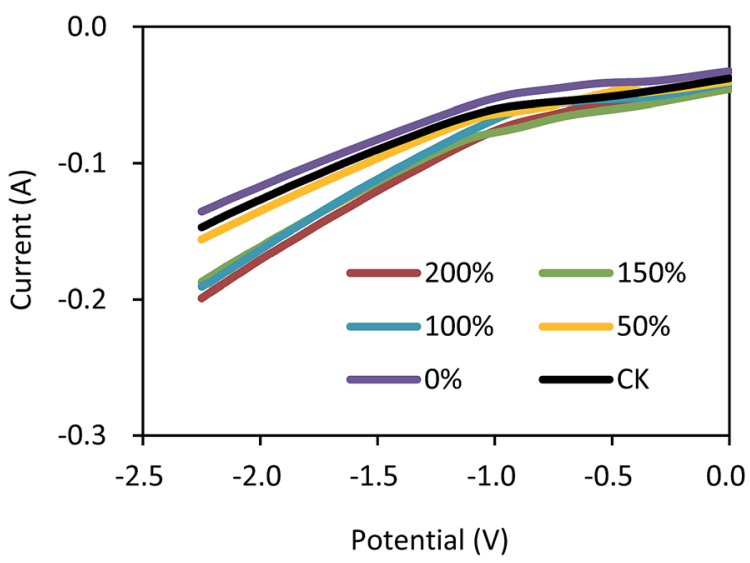

Fig. 3 Linear sweep voltammetry measurement on the gas diffusion cathode with different ratios of $\mathrm{Na}_{2} \mathrm{SO}_{4}$ to carbon black.
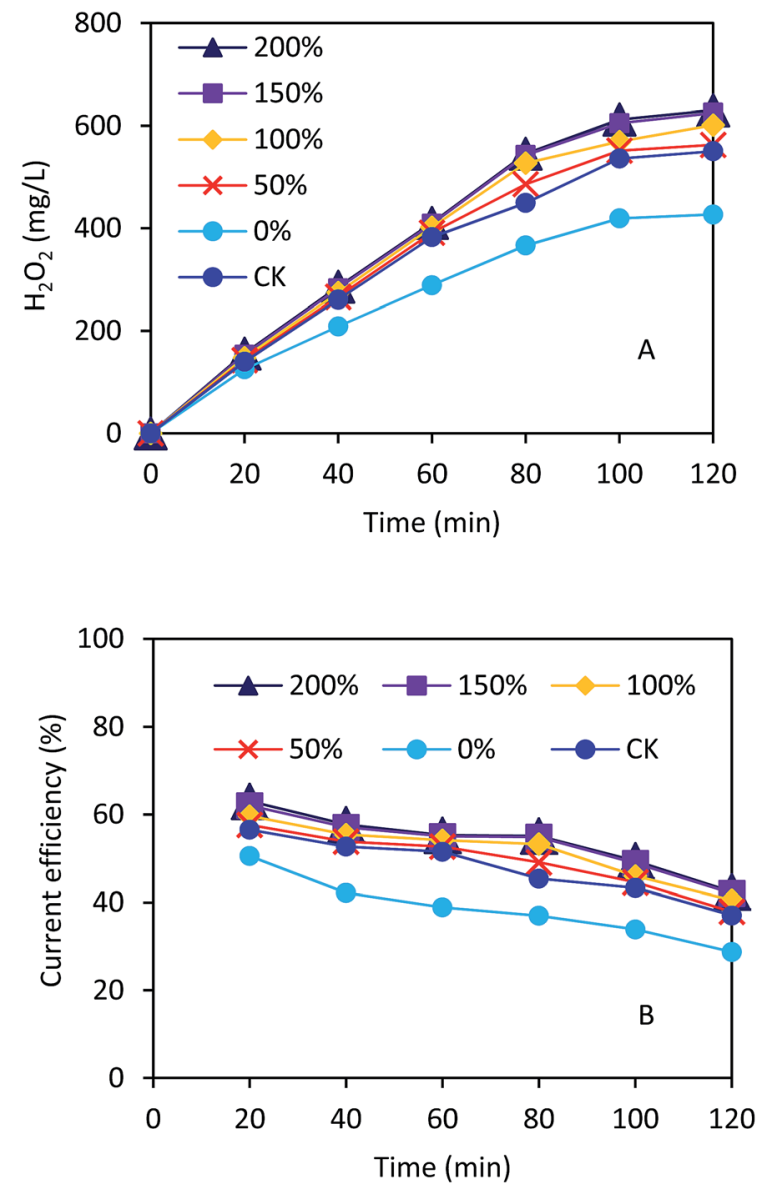

Fig. 4 (A) $\mathrm{H}_{2} \mathrm{O}_{2}$ concentration and (B) current efficiency in the electrochemical cell using the gas diffusion cathode with different ratios of $\mathrm{Na}_{2} \mathrm{SO}_{4}$ to carbon black.

The GDCs with the ratios of $150 \%$ and $200 \%$ had almost the same $\mathrm{H}_{2} \mathrm{O}_{2}$ concentration of $630 \mathrm{mg} \mathrm{L^{-1 }}$ within $120 \mathrm{~min}$. The $\mathrm{H}_{2} \mathrm{O}_{2}$ concentrations were 427,562 , and $601 \mathrm{mg} \mathrm{L}^{-1}$ with the ratios of $0 \%, 50 \%$, and $100 \%$ within $120 \mathrm{~min}$, respectively. The CK had higher $\mathrm{H}_{2} \mathrm{O}_{2}$ concentration than that with $0 \% \mathrm{Na}_{2} \mathrm{SO}_{4}$ within $120 \mathrm{~min}$ (550 vs. $427 \mathrm{mg} \mathrm{L}{ }^{-1}$ ). The current efficiencies increased from $29 \%$ to $38 \%$ with the ratios from $0 \%$ to $50 \%$ within $120 \mathrm{~min}$ (Fig. 4B). However, the current efficiencies were not significantly improved and kept in a range of 38\%-42\% with the ratios from $50 \%$ to $200 \%$ within 120 min. The $\mathrm{H}_{2} \mathrm{O}_{2}$ concentrations and current efficiency in this study were comparable to those in other $\mathrm{H}_{2} \mathrm{O}_{2}$ electrochemical generation processes using GDCs. ${ }^{30,31}$ Nevertheless, our results demonstrated that the pore former could improve the $\mathrm{H}_{2} \mathrm{O}_{2}$ production in the electrochemical process, which should be important for the EF application in practice.

\subsection{CBZ degradation in the electro-Fenton with different GDCs}

Under the condition of current density of $5.0 \mathrm{~mA} \mathrm{~cm}{ }^{-2}$ and $4.56 \mathrm{~g} \mathrm{~L} \mathrm{~L}^{-1}$ ferrous sulfate, the CBZ removal efficiencies increased with the running time in the EF process (Fig. 5A). The 

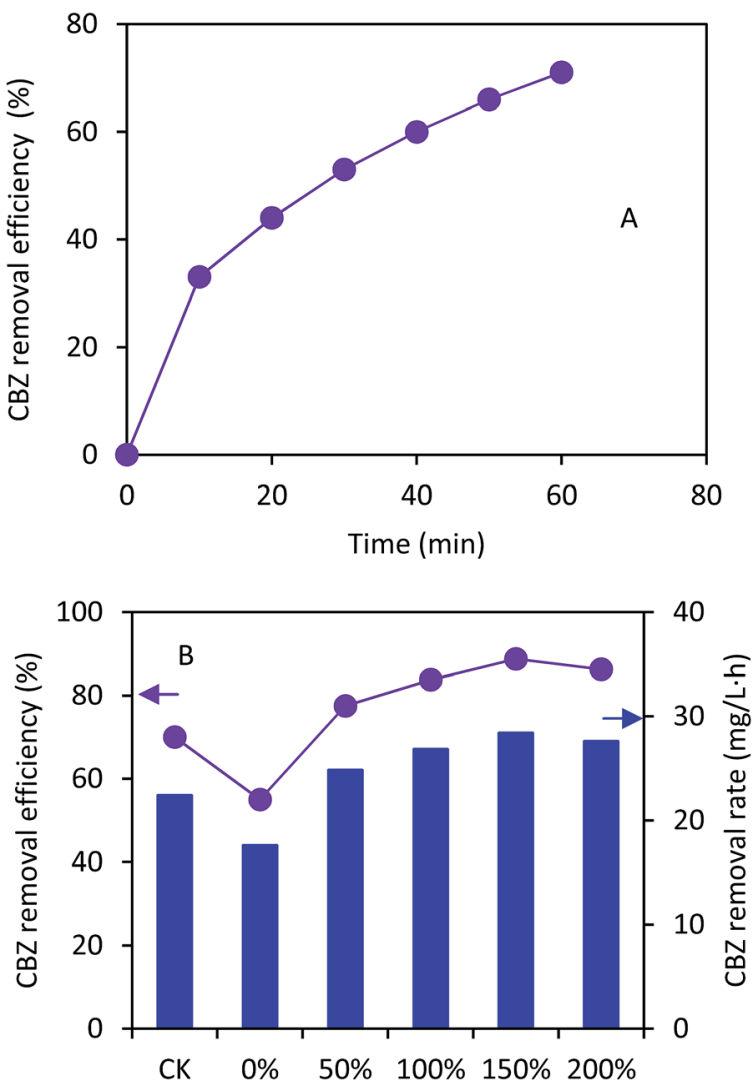

Mass ratio of sodium sulfate to carbon black

Fig. 5 (A) CBZ removal change with time in the electrochemical cell using the gas diffusion cathode with the $\mathrm{Na}_{2} \mathrm{SO}_{4}$ to carbon black ratio of $150 \%(\mathrm{w} / \mathrm{w})$; (B) change with ratios of $\mathrm{Na}_{2} \mathrm{SO}_{4}$ to carbon black within 60 min (initial conditions: $4.56 \mathrm{~g} \mathrm{~L}^{-1} \mathrm{FeSO}_{4}, 50 \mathrm{mg} \mathrm{L}^{-1} \mathrm{CBZ}$; operation conditions: $\mathrm{pH}=3.0$ and $5.0 \mathrm{~mA} \mathrm{~cm}^{-2}$ current density). maximum CBZ removal efficiency reached 71\% using the GDC with the ratio of $\mathrm{Na}_{2} \mathrm{SO}_{4}$ to carbon black of $150 \%$ within $60 \mathrm{~min}$, which was much higher than that with $0 \%$ (44\%) (Fig. 5B). The CBZ removal efficiencies were $62 \%, 67 \%$, and $69 \%$ with the ratios of $50 \%, 100 \%$, and $200 \%$, respectively. The CBZ removal of the control (56\%) was lower than that with the $\mathrm{Na}_{2} \mathrm{SO}_{4}$ addition, indicating that the pore former could enhance the EF process. The ratio of $200 \%$ resulted in lower CBZ removal than $150 \%$, probably because of excess oxygen competition with CBZ during the EF process. ${ }^{32}$ Our results demonstrated that high concentration of $\mathrm{CBZ}$ (e.g. $50 \mathrm{mg} \mathrm{L}^{-1}$ ) could be efficiently removed in the EF process. A control test showed that the adsorption of CBZ on the GDC was $9.8 \pm 0.5 \%$ within $60 \mathrm{~min}$. Therefore, the CBZ removal in the EF process was mainly attributed to the oxidation by hydroxyl radicals.

Table 2 compares the CBZ removal results based on the Fenton, electro-Fenton and Fenton-like processes. While the CBZ removal efficiencies with the different processes were comparable, the CBZ removal rates in this study were much higher than those in the literature. ${ }^{17-19,33,34}$ The highest CBZ removal rate reached $35.5 \mathrm{mg} \mathrm{L}^{-1} \mathrm{~h}^{-1}$ using the GDC, which was about five and nine times higher than those using the Fentonlike process with the initial CBZ concentration of $15 \mathrm{mg} \mathrm{L}^{-1}$ and $100 \mathrm{mM} \mathrm{H}_{2} \mathrm{O}_{2}\left(7.5 \mathrm{mg} \mathrm{L}^{-1} \mathrm{~h}^{-1}\right)^{34}$ and the electro-Fenton process (4.0 mg $\left.\mathrm{L}^{-1} \mathrm{~h}^{-1}\right),{ }^{17}$ respectively. Full dosage of $\mathrm{H}_{2} \mathrm{O}_{2}$ was added at the beginning of the Fenton or Fenton-like process. ${ }^{19,33,34}$ The CBZ removal could take several hours via the Fenton or Fenton-like process, indicating that $\mathrm{H}_{2} \mathrm{O}_{2}$ was consumed gradually. However, residual $\mathrm{H}_{2} \mathrm{O}_{2}$ could compete with CBZ for exhausting the hydroxyl radical (eqn (4)) ${ }^{35}$ and hinder high CBZ removal rate:

Table 2 The comparison on the CBZ removal using different Fenton process

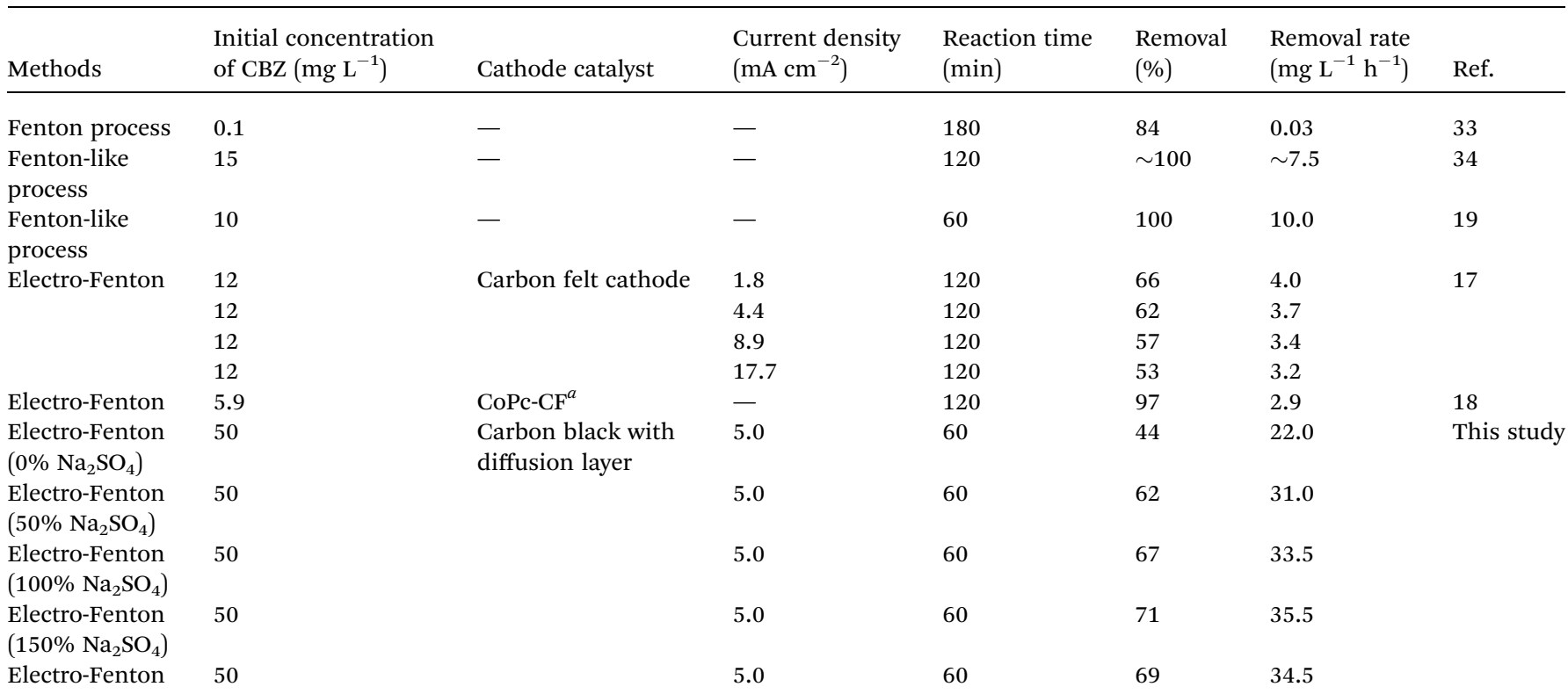

$\left(200 \% \mathrm{Na}_{2} \mathrm{SO}_{4}\right)$

${ }^{a}$ CoPc-CF: carbon fiber coupled with cobalt phthalocyanine. 


$$
\mathrm{H}_{2} \mathrm{O}_{2}+{ }^{\cdot} \mathrm{OH} \rightarrow \mathrm{HO}_{2} \cdot+\mathrm{H}_{2} \mathrm{O}
$$

In the electro-Fenton process with carbon felt or carbon fiber coupled with cobalt phthalocyanine (CoPc-CF) as cathode, ${ }^{17,18}$ without a diffusion layer in the cathode, the $\mathrm{H}_{2} \mathrm{O}_{2}$ concentration in the solution is usually pretty low. Fox example, the maximum $\mathrm{H}_{2} \mathrm{O}_{2}$ concentration was $1.44 \mathrm{mg} \mathrm{L}^{-1}$ after 120 min operation at the current density of $17.7 \mathrm{~mA} \mathrm{~cm}{ }^{-2}(2.0 \mathrm{~V})$ in the electro-Fenton with carbon felt cathode. ${ }^{17}$ Only $3.54 \mathrm{mg} \mathrm{L}{ }^{-1}$ of the $\mathrm{H}_{2} \mathrm{O}_{2}$ concentration was produced after $30 \mathrm{~min}$ operation in the electro-Fenton with CoPc-CF cathode with an applied voltage of $2.5 \mathrm{~V}^{18}$ However, because of high oxygen transfer coefficient in the diffusion layer of GDC, the $\mathrm{H}_{2} \mathrm{O}_{2}$ concentrations reached $150 \mathrm{mg} \mathrm{L}^{-1}$ within $20 \mathrm{~min}$ and $630 \mathrm{mg} \mathrm{L}^{-1}$ within $120 \mathrm{~min}$ operation in this study. The $\mathrm{H}_{2} \mathrm{O}_{2}$ concentrations gradually increased with the operation time, which reduced the chance of excess $\mathrm{H}_{2} \mathrm{O}_{2}$ accumulation and thus the reaction of eqn (4) might not occur. Therefore, high CBZ removal rate could be achieved in our electro-Fenton with GDC. Nevertheless, the CBZ removal varies with different conditions, including initial CBZ concentration, type of catalysts, current density, electrolytes, and others. ${ }^{17-19,33,34}$ It was difficult to make accurate comparison under the different conditions.

The GDC in the EF process is different from that in fuel cells, such as the proton exchange membrane fuel cell. ${ }^{26,29}$ Since the catalyst layer in the GDC in the EF process faces to aqueous solution, the diffusion layer in the EF should prevent the electrolyte leakage through the cathode. ${ }^{36,37}$ The specific requirement in the diffusion layer may limit the design of the pore structure of the diffusion layer using pore former, which should be further explored. Moreover, the life-time of the diffusion layer with pore former still needs to be investigated.

\section{Conclusions}

Different ratios of $\mathrm{Na}_{2} \mathrm{SO}_{4}$ to carbon black in the diffusion layer were investigated in the $\mathrm{EF}$ process for $\mathrm{H}_{2} \mathrm{O}_{2}$ production and CBZ removal. With increase of the ratios, the average pore size in the diffusion layer and the oxidation and reduction activity in the GDC increased simultaneously, resulting in high mass transfer coefficient of oxygen and $\mathrm{H}_{2} \mathrm{O}_{2}$ production. Under the current density of $5.0 \mathrm{~mA} \mathrm{~cm}{ }^{-2}$, the maximum $\mathrm{H}_{2} \mathrm{O}_{2}$ concentration of $630 \mathrm{mg} \mathrm{L}^{-1}$ was achieved with the ratio of $150 \%$ within $120 \mathrm{~min}$. With the initial CBZ concentration of $50 \mathrm{mg} \mathrm{L}^{-1}$ and $5.0 \mathrm{~mA} \mathrm{~cm}{ }^{-2}$, the maximum CBZ removal efficiency and rate reached $71 \%$ and $35.5 \mathrm{mg} \mathrm{L}^{-1} \mathrm{~h}^{-1}$, respectively, using the GDC with the ratio of $150 \%$ within $60 \mathrm{~min}$. Our experimental results demonstrated that the pore former can be used to optimize the pore structure of diffusion layer and to enhance the EF performance to CBZ removal in wastewater treatment.

\section{Acknowledgements}

This work was partly supported by grants from the National Natural Science Foundation of China (No. 51278500, 41471181, and 51308557), the Natural Science Foundation of Guangdong
Province (S2013010012984), the Science and Technology Program of Guangzhou (No. 201604010043), and the Fundamental Research Funds for the Central Universities (16lgjc65).

\section{References}

1 M. A. Oturan and J.-J. Aaron, Crit. Rev. Environ. Sci. Technol., 2014, 44, 2577-2641.

2 G. Ren, M. Zhou, M. Liu, L. Ma and H. Yang, Chem. Eng. J., 2016, 298, 55-67.

3 Z. Qiang, J.-H. Chang and C.-P. Huang, Water Res., 2002, 36, 85-94.

4 E. Brillas, I. Sirés and M. A. Oturan, Chem. Rev., 2009, 109, 6570-6631.

5 H. Luo, C. Li, C. Wu, W. Zheng and X. Dong, Electrochim. Acta, 2015, 186, 486-493.

6 G. Santana-Martínez, G. Roa-Morales, E. Martin del Campo, R. Romero, B. A. Frontana-Uribe and R. Natividad, Electrochim. Acta, 2016, 195, 246-256.

7 Y. Liu, S. Chen, X. Quan, H. Yu, H. Zhao and Y. Zhang, Environ. Sci. Technol., 2015, 49, 13528-13533.

8 H. Luo, C. Li, C. Wu and X. Dong, RSC Adv., 2015, 5, 6522765235.

9 G. Inoue, K. Yokoyama, J. Ooyama, T. Terao, T. Tokunaga, N. Kubo and M. Kawase, J. Power Sources, 2016, 327, 610-621. 10 E. Brillas, J. C. Calpe and J. Casado, Water Res., 2000, 34, 2253-2262.

11 P. Braeutigam, M. Franke, R. J. Schneider, A. Lehmann, A. Stolle and B. Ondruschka, Water Res., 2012, 46, 24692477.

12 D. P. Mohapatra, S. K. Brar, R. D. Tyagi, P. Picard and R. Y. Surampalli, Talanta, 2012, 99, 247-255.

13 Y. Liu, S. Mei, D. Iya-Sou, S. Cavadias and S. Ognier, Chem. Eng. Process., 2012, 56, 10-18.

14 M. Suhasini, E. Sailatha, S. Gunasekaran and G. R. Ramkumaar, Spectrochim. Acta, Part A, 2015, 141, 252-262.

15 J. Sipma, B. Osuna, N. Collado, H. Monclús, G. Ferrero, J. Comas and I. Rodriguez-Roda, Desalination, 2010, 250, 653-659.

16 Y. Zhang, S.-U. Geißen and C. Gal, Chemosphere, 2008, 73, 1151-1161.

17 S. Komtchou, A. Dirany, P. Drogui and A. Bermond, Environ. Sci. Pollut. Res., 2015, 22, 11513-11525.

18 M. Liu, H. Xia, W. Lu, T. Xu, Z. Zhu and W. Chen, J. Appl. Electrochem., 2016, 1-10.

19 V. M. Monsalvo, J. Lopez, M. Munoz, Z. M. D. Pedro, J. A. Casas, A. F. Mohedano and J. J. Rodriguez, Chem. Eng. J., 2015, 264, 856-862.

20 N. Li, J. An, L. Zhou, T. Li, J. Li, C. Feng and X. Wang, J. Power Sources, 2016, 306, 495-502.

21 J. F. Pérez, J. Llanos, C. Sáez, C. López, P. Cañizares and M. A. Rodrigo, Electrochem. Commun., 2016, 71, 65-68.

22 H. Tang, S. Wang, M. Pan and R. Yuan, J. Power Sources, 2007, 166, 41-46.

23 J. R. Kim, S. Cheng, S.-E. Oh and B. E. Logan, Environ. Sci. Technol., 2007, 41, 1004-1009. 
24 X. Y. Zhang, S. A. Cheng, X. Wang, X. Huang and B. E. Logan, Environ. Sci. Technol., 2009, 43, 8456-8461.

25 Standard Methods for the Examination of Water and Wastewater, ed. L. S. Clesceri, A. E. Greenberg and A. D. Eaton, American Public Health Association, Washington, DC, 20th edn, 1998.

26 J. H. Chun, K. T. Park, D. H. Jo, J. Y. Lee, S. G. Kim, E. S. Lee, J.-Y. Jyoung and S. H. Kim, Int. J. Hydrogen Energy, 2010, 35, 11148-11153.

27 G. Selvarani, A. K. Sahu, P. Sridhar, S. Pitchumani and A. K. Shukla, J. Appl. Electrochem., 2008, 38, 357-362.

28 S. W. Park and D. G. Lee, Composites, Part A, 2010, 41, 15971604.

29 J. Liu, C. Yang, C. Liu, F. Wang and Y. Song, Ind. Eng. Chem. Res., 2014, 53, 5866-5872.

30 X. Yu, M. Zhou, G. Ren and L. Ma, Chem. Eng. J., 2015, 263, 92-100.
31 R. M. Reis, A. A. G. F. Beati, R. S. Rocha, M. H. M. T. Assumpção, M. C. Santos, R. Bertazzoli and M. R. V. Lanza, Ind. Eng. Chem. Res., 2012, 51, 649-654.

32 L. Zhou, M. Zhou, C. Zhang, Y. Jiang, Z. Bi and J. Yang, Chem. Eng. J., 2013, 233, 185-192.

33 D. P. Mohapatra, S. K. Brar, R. D. Tyagi, P. Picard and R. Y. Surampalli, Sci. Total Environ., 2013, 447, 280-285.

34 S. P. Sun, Z. Xia, C. Li and A. T. Lemley, Chem. Eng. J., 2014, 244, 44-49.

35 H. Zhang, D. Zhang and J. Zhou, J. Hazard. Mater., 2006, 135, 106-111.

36 T. Harrington and D. Pletcher, J. Electrochem. Soc., 1999, 146, 2983-2989.

37 Y. Lei, H. Liu, Z. Shen and W. Wang, J. Hazard. Mater., 2013, 261, 570-576. 